\title{
Kiralık Konak Romanında Özgür Olmayıș Fenomeni
}

\section{Oğuz ÖCAL*}

\begin{abstract}
ÖZ
Kiralık Konak, insan varlığını tehdit eden unsuru, özgür olmayış durumu olarak görünüşe çıkaran bir romandır. Kısa bir ifadeyle, özgür oluşun (sorumlu oluşun) olumsuz şekli olan özgür olmayış durumu, kişinin yaşadığ gereken olanaklarını, tepkisel nitelikli eylemleriyle kapatmasıdır. Esir oluştan niteliksel olarak farklı olan özgür olmayış, içinde olunan pek çok durum gibi, insana, farkına varıldığında en yakın, öyle olmadığında ise en uzak durum olarak var olur ve kendisini, sözlerle eylemlerde görünüşe çıkarır. Aynı zamanda olumsuz bir durumun ismi de olan bu fenomen, adı geçen romanda, asıl kişi Seniha'nın olanaklarını israf edişinde görünüşe çıkar. Diğer bir ifadeyle romanın varlık nedeni de olan Seniha, yaşadığı karşılaşmalarla açılan olanaklarını, kullanıp atma düşkünlüğünden dolayı kapatırken özgür olmadığını da ortaya koyar. $\mathrm{Bu}$ bağlamda romanı değerli kılan husus ise, insan varlığını tehdit eden unsuru, özgür olmayış durumu olarak somutlamasıdır.

$\mathrm{Bu}$ yazıda önce, kavramın kısa bir tanımı yapılmış ve asıl kişinin eylemlerini belirleyen en derin unsurun özgür olmayış durumu olduğu ortaya konmuştur. Daha sonra ise kapatma ve kaçış düşkünlüğünün dolaylı nedenleri tartışılmış ve bu hususun doğrudan nedeninin özgür olmayış durumu olduğu iddia edilmiştir.
\end{abstract}

Anahtar Kelimeler: Kiralık Konak, özgür olmayış fenomeni, düşkünlük, varlık ve tehlike.

* Doç. Dr. Kırıkkale Üniversitesi, Fen-Edebiyat Fakültesi, Türk Dili ve Edebiyatı Bölümü, Kırıkkale/Türkiye E-posta: ogzocal@yahoo.com

Makale Gönderim Tarihi: 15.11.2017 * Makale Kabul Tarihi: 25.10.2018 


\section{ABSTRACT \\ The Phenomenon of Not Being Free In The Novel of Kiralık Konak}

Kiralık Konak is the novel that makes visible the factor threatening to human existence as the situation of not being free. Shortly, the situation of not being free is the negative form of being free (being responsible). The situation of not being free is making close of person's own oppotunities with the reactional qualified actions. These opportunities are opportunities which appear with person's encountering thing and need to be evaluated urgently. It is different from the captivity qualitatively. The situation of not being free is the closest situation when it is noticed, it is the farthest situation when it is not noticed for person like many situation which is been inside. And it makes itself visible with words and actions. At the same time, the phenomenon of not being free which is also name of a negative situation shows up in wasting of the main character Seniha's opportunities in this novel. In other words, Seniha who is also the existence reason of novel makes close own opportunities which is opened with encountering to realities of herself and people because she is fond of instrumentalization which means to use and throw. Thus she shows that not being free. In this context, we should say that the thing which makes precious this novel is making visible the factor threatening to human existence as not being free.

In this article, firstly the concept is described shortly. And it is proved that the situation of not being free is the deepest factor determining main character's actions. After, it is discussed that the indirect reasons of fond of closing and escape. And it is claimed that not being free is the direct reason of this situation.

Keywords: Kiralık Konak, the phenomenon of not being free, fondness, existence and danger. 


\section{Giriş}

I çine doğduğu dünyanın zihniyeti tarafından biçimlendirilen insanın şahsında gerçekleştirmesi gereken hususlardan birisi de özgürlüktür. Teorik nitelikli bir fenomen olan özgürlük ve onun pratik şekli olan özgür oluş, dış baskı ve zorlamanın yokluğunda, insanın önce kendisine ve daha sonra da dünyaya ait olanaklarını, bütünselliği olan bir sorumluluk bilinciyle değerlendirmesi demektir (Mengüşoğlu 1988: 129-139). Bu hususun tam karşısında yer alan özgür olmayış durumu ise, insanın üzerinde herhangi bir baskı ve zorlama olmadığı hâlde, sorumsuz davranarak olanaklarını harcamasını ifade eder. Özgürlüğün her iki şekli de, birer seçimi içerir ve aynı zamanda içinde olunan birer durumu işaret eder. Söz konusu bu durum, farkına varıldığında insana, kendisini yenileyip canlandırma olanağı sunarken öyle bir farkındalık olmadığında ise, çoğunlukla, zaman israfina neden olur. Örneğin, olanaklarını zengin bir koca ararken harcayan ve hayal kırıklığına uğrayan bir kadının içinde bulunduğu durumu aşmak yerine, onu olduğu gibi bırakması, basit de olsa bir seçimdir. Ve bu seçim, öncelikle öznesinin, özgürlügüüü, yani olanaklarını, sorumlu değil de keyfi bir şekilde değerlendirdiğini, dolayısıyla da içinde olduğu durumun farkında olmadığını imler. Elbette, örnek gösterilen kişinin yaptı̆̆ 1 seçimde, iç içe geçmiş durumda olan zaman, mekân, irsiyet ve zihniyet gibi kategorilerin de etkisi olmuştur. Ancak o eylemin en kökten nedeni ise, onu gerçekleştiren kişinin hem içinde olduğu hem de farkında olmadığı özgür olmayış durumudur. Buradan da çıkarılacağı gibi, gerçekleşen seçimin, dolayısıyla da eylemin sorumluluğu, doğrudan o kişinin kendisine aittir. Diğer nedenler ise, dolaylı birer unsur olarak özgürlük tasarrufundan sonra gelir.

Özgür oluş ile olmayış fenomenleri, insana, el altındaki bir nesne kadar yakın, ancak yakınlığı fark edilmediği için de bir o kadar uzak olan birer durumu işaret eder ve bu iki husus da, birer nedene dönüşerek kendisini, en iyi şekilde, romanda görünüşe çıkarır. Öyle ki ilk örneklerinden günümüze kadar roman, yaşanan bir dramı konu almış ve onun nedenini ise çoğunlukla -bu çalışmanın bakış açısına göre- özgür olmayış durumu olarak görünür kılmıştır. Bir diğer ifade ile bugüne kadar gelen romanımızda, daha önce de gözlemlendiği gibi, anlatılan dramların nedeni olarak bireyi ya da toplumu öne çıkaran iki eğilim dikkati çeker. Bu iki eğilimden ilkini, kurulu düzenle uyumlu ve Doğu-Batı çatışmasını bir çözüme ulaştırmaya çalışan romancılarımız oluşturur (Moran 1995: 244-250) ve onlar, anlattıkları dramın doğrudan nedeni olarak, içinde olunan ancak farkında olunmayan duruma vurgu yaparlar. İkinci eğilimi ise yaşanan ve anlatılan dramın nedeni olarak kurulu düzeni işaret eden ve ezenezilen ilişkisini öne çıkaran romancılarımız oluşturur (Moran 1994: 237- 
244). Bu iki eğilimden birincisi, liberal kapitalist; ikincisi ise, sosyalist bir zihniyete ve dünya görüşüne sahiptir. Birinci eğilim, benimsediği anlayışa uygun şekilde bireyi sorumlu kılar ve dış dünyayı dolaylı bir neden olarak işaret ederken ikinci eğilim, kurulu düzeni suçlar ve onu sorumlu tutar.

Söz konusu eğilimlerden ilkinin bir temsilcisi olan ve yaşanan dramın nedeni olarak bireyin içinde olduğu duruma vurgu yapan romancılarımızdan birisi de Yakup Kadri Karaosmanoğlu'dur. Seçkin bir sanatçı olan Yakup Kadri, başlangıçtaki bireyci zihniyetini terk ettikten sonra dayanışmacı bir anlayışı benimser ve benimsediği bu anlayışa uygun olarak da dokuz roman kaleme alır. Onun yayınlanan ilk romanı ise bilindiği gibi, Kiralık Konak'tır. Daha önce, içerdiği çatışmalar ile farklı tematik bağlamlar dikkate alınarak okunan Kiralık Konak, bu çalışmanın bakış açısına göre, insan varllğını tehdit eden unsuru, özgür olmayış durumu olarak görünür kılan bir romandır. Aynı zamanda içinde olunan olumsuz bir durumun ismi de olan bu husus ise, hâkim anlatıcı tarafından sunulan romanda, asıl kişi Seniha'nın yaşadığı karşılaşmalardan sonra açılan olanaklarını kapatarak onlardan uzaklaşmasıyla görünür hâle gelir.

\section{Yaşanan İlk Kriz, Faik Bey ile Karşılaşma ve İlk Seçim}

Asriliği rahat, kayıtsız ve sorumsuz yaşamak olarak anlayan bir baba ile şaşkın bir annenin kızı olan Seniha, özel mürebbiyesi olan, on yedi on sekiz yaşlarında bir genç kızdır. Büyükbabası Naim Efendi'ye ait bir konakta, ailesiyle birlikte yaşamını sürdürür. Anlamsal boşluk içindedir ve her şeyi az, adi ve dar olarak görür. Bunun için de ait olduğu kültür ve medeniyete dair her şeyden nefret eder. Öyle bir durumda iken, başta mürebbiyesinin anlattıkları olmak üzere, okuduğu romanların da yönlendirmesiyle, kendisine bir yaşama amacı belirler. O, özellikle Paris'e giderek orada her kayıttan azade, baskısız ve keyfi bir yaşam sürmeyi istemektedir. Geçen zaman içinde çevresine karşı duyduğu nefretle başka yerlere duyduğu özlem, yaşamının amacını daha kararlı bir hâle getirmesine olanak sağlar. Ancak o, maddî olarak çok "sefalete düştük"lerini (31) anlayınca, isteğiyle durumun gerçeği arasında sıkışır kalır. Ne isteğini dönüştürür ne de gerçeği olduğu gibi kabul eder. Dolayısıyla da yaşadığı bunalımla derinleşen krizini aşamadığı için, bir çıkmaza girer. Ailesi, doktorunun da tavsiyesiyle onu, iyileşmesi için, Büyükada'da yaşayan halası Necibe Hanım'ın yanına gönderir. Orada, zaten "içkiye ve saza" karşı "yaşla hiç sönmeyen bir düşkünlügüu” (47) olan Necibe Hanım'ın teşviki ve kardeşi Cemil'in girişimleri ile kısa bir süre içinde, Seniha'yı rahatlatabilecek bir eğlence ortamı oluşturulur. Oluşan bu ortamda 
Seniha, biraz sakinleşir ve "hayatta[ki] yegâne emeli seçkin ve zengin bir dulla evlenmek" (45) olan kardeşinin arkadaşı Faik Bey'le yakınlaşır. Sadece genç kadınlara değil, aynı zamanda kumara da düşkün olan Faik Bey, kısa bir süre içinde, hem Seniha'nın Paris'e dair düşlerini besler, hem de onları gerçekleştirebilecek bir potansiyele sahip olduğu için, onun yoğun ilgisiyle karşılaşır. Seniha, daha önce nefret ettiği Faik Bey’e karşı duyduğu ilginin beraberinde getirdiği hava ile yeniden eski haline gelir. Ancak bu canlılık, çok kısa bir süre sonra kaybolur ve ne olduğu tam olarak belli olmayan ilişkinin büyüsü bozulmaya başlar. O esnada Seniha, kumar borcunu ödeyebilmek için kendisinden borç para isteyen Faik Bey'i, gerçekliği içinde olduğu gibi görür. İtiraf etmese de kendisi için bir kurtarıcı olabileceğini sandığı kişinin aslında düşkün birisi olduğunu fark edince hayal kırıklığına uğrar ve umutlanarak bastırdığı krizi, yeniden canlanır. Çincede kriz sembolü, iki unsurdan oluşur: Biri tehlikeye, diğeri de olanağa işaret eder. (Mumford 2015: 523). Hem bekâretini kaybetmesi hem de düşlerinin bir aracını yitirmiş olmasıyla ortaya çıkan durum ise Seniha'ya, iki olanak sunar ve onu özgürlüğüyle karş1 karşıya bırakır. Olanaklarının sınırında duran ve seçim yapmak zorunda olan Seniha, ya yaşadığı çift boyutlu kayıptan sonra isteklerini gözden geçirecek ya da Faik Bey'e bağlı olmadığını ispat edercesine, daha hırslı bir şekilde, amacına ulaşmak için, arayışına hız verecektir. Bir diğer ifadeyle, ya gerçeği olduğu gibi görüp aşacak ya da keyfi eyleme düşkünlüğüne bağlı kalarak açılan olanăg kapatacaktır. O, hırslı olmayı, kararlı olmaktan ayıramadığ 1 için, ikinci olanağı seçer.

"Seniha kalbimin bu bir günlük imtihanından epeyce değişmiş çıktı. Aşktan evvelki alaycı, havai, şuh ve işveli hâline avdet etti. Cemil'in dostlarından Macit Bey'le küçük bir macerası oldu. Pangaltı'daki İtalyan ahbaplarına sık sık gitmeye başladı; orada bir genç adamdan dans dersleri aldığını söylüyordu. Yeniden Nuriye, Neyyire ve Belkıs Hanımlar her gün için konağa doldular. Seniha'daki bu ani değişiklik pek ziyade meraklarını uyandırıyordu. Belkıs Hanım'ın gözlerinde kendisine bakarken: “Zavallı! Nihayet bırakıldı mı? Oh olsun!" diyen bir nazar vardı; Nuriye ve Neyyire ağzını aramak için yavaş yavaş Faik Bey'in aleyhinde bulunuyorlard1. Seniha bu zandan kurtulmak için elinden geleni yaptı, birbirini takip eden flörtlerine pervasız bir aleniyet verdi. Gizli kalan taraflarını da kendisi anlatmaya başladı" (94-95).

Seniha, alıntılanan metinde de görülebileceği gibi, yaşadığı bu ilk kriz esnasında, karşısına çıkan kendisini aşma olanağını, özgür olmadığ 1 için kapattıktan hemen sonra, çevresindekilerin dedikodularına karşılık verebilmek için, daha da kötü bir duruma düşme ihtimalini umursamadan eylemlerine aleniyet verir. Gerek yaptığı seçimi gerekse o eyleminden 
sonra ortaya koyduğu tepkisel tavrı ise, onun öfkesine ve insanların kendisi hakkındaki yorumuna esir olduğunu, dolayısıyla da özgür olmadığını ortaya koyar.

\section{İkinci Kriz, Naim Efendi ile Karşılaşma ve Kaçış}

Öfkeyle hareket eden Seniha, geçen zaman içinde, başta Faik Bey olmak üzere, birçok erkekle birlikte olur ve düşleri için kendisine çok para gerektiğini anımsayınca da "her vasıtadan fayda" (89) ummaya başlar. Aynı zamanda kendisine, "geniş ve muhteşem ufku açacak" (98) bir kahraman bekleyişi içinde de olan Seniha, çevresindeki kadınlarla yaptığı konuşmalardan sonra, kontrolünü kısmen de olsa yitirir ve bütün meselenin "zengin [bir] koca" (117) bulmakta olduğuna iyice kanaat getirir. Bu arada Faik Bey'i çok iyi tanıdığ 1 için, ne onu bütünüyle terk eder ne de onunla evlenmek ister. Evliliği "paraya müteallik bir iş" (109) olarak telakki eden Seniha, yaptığı bu ilk seçimden sonra, çok daha açık bir şekilde tüccara dönüşür: Neredeyse yegâne amac1, olanaklarını sunup karşıllğını alabileceği zengin bir sevgili bulmak olur. Bu arada babası, pek çok kayıttan azade olmasına rağmen, kızının keyfi davranışlarını kabul edilemez bulur. Ancak öteden beri sorumluluk üstlenmek çıkarına uymadığı için, sorunun çözümünü Naim Efendi’ye bırakır. Ailesi üzerindeki etkisinin "hiçe in[mek]" (77) üzere olduğunu anlayan Naim Efendi ise, iyi niyetli bir şekilde davranarak son bir hamlede bulunur ve değerlere karşı saygısız davranan gençleri evlendirip sorunu çözmek ister. Bunun için de Faik Bey'in önceden beri tanıdığ 1 babası Kasım Paşa'yı ziyaret eder ve düşüncesinden bahsederek ondan kendisine yardım etmesini ister. Ancak Kasım Paşa, oğlunun zengin bir kızla evlenmesini istediği için, riyakâr davranır ve Naim Efendi'yi ikna ederek başından savar. Bu arada Seniha, büyükbabasının girişiminden haberdar olur ve öfkeli bir şekilde, ona, kendisiyle ilgili kararlara karışmaması gerektiğini söyler. Üstelik büyükbabasını saygısızca payladıktan sonra, bir mektup yazarak onun yaptığı yanlışı düzeltmek ister. Çok açıkça bir çatışmayı içeren bu durum, Seniha'yı, kendisine ve ailesine ait gerçeklikle karşılaştırır. $\mathrm{O}$, bu karşılaşmadan sonra, yeniden özgürlüğü ile baş başa kalır ve acil olarak bir seçim yapmak zorundadır. Daha önce olduğu gibi karşısında, yine iki olanak vardır. O, ya maddî olarak bağlı olduğu ailesiyle yaşadığı çatışmayı çözerek tarihselliğini gerçekleştirecek ya da kolay olanı seçerek oradan uzaklaşacaktır. Söz konusu olanaklardan birincisi açıcıdır ve ona pek çok şeyi değiştirerek devam ettirme imkânı sunar. İkincisi ise, sahih değişim ve yenilenme olanağını bloke edici ve kapatıcıdır. Açmak ile kapatmak olanaklarının sınırında duran Seniha, durumunun iyiliğinden 
hiç şüphelenmediği için, dâhil olduğu kültür ve medeniyete karşı duyduğu nefretin de belirlemesiyle, maddî hiçbir teminatı olmamasına rağmen, ikinci olanağı tercih eder:

"Siz zannediyor musunuz ki ben ömrümün sonuna kadar böyle bir kalacağım? Böyle bir memlekette, etrafımda böyle bir halkla? Bin güçlükle senede ancak beş on kat esvap yaptırarak, ara sıra Ada’ya misafirliğe giderek ve pazartesi günleri aşağıda salonda birkaç manasız ve yavan davetli bekleyerek yaşayıp gideceğim? Hayır! Büyükbaba, ben o kadar basit ruhlu bir kız değilim! Çok okudum; çok öğrendim; çok düşündüm; çok tahlil ettim. Biliyorum ki hayat denilen şey, içinde doğup büyüdüğüm bu hapishanenin dışında gürültülü, geniş, aydınlık, acayip, hazin, neşeli, düz, yılankavi, inişli yokuşlu bitmez tükenmez bir sahadır. Oradan bin türlü sesler işitiyorum; bu sesler her biri başka tarzda, bir başka lisanda bana 'gel' diyor. Kendimi güç zapt ediyorum. Fakat bugün değilse yarın mutlaka bu seslerden birisine doğru koşacağım. Mutlaka!" (110).

Seniha, bu ifadelerinden de anlaşılabileceği gibi, maddî olarak bağlı olduğu büyükbabasıyla konuşurken kendisini özgür bir insan gibi ortaya koyar ve pervasızca aldığı karara saygı gösterilmesini ister. Ancak onun bu ifadeleri, özgürce seçip sorumluluk üstlenen bir insanı değil, keyfiliği özgürlük sanan ve olanaklarını kolaylıkla harcayabilen bir insan olduğunu ortaya koyar. Oysa özgürlük, keyfi davranmak değil, bağlanmak ve hiçbir bahaneye sığınmadan tepeden tırnağa sorumlu olmaktır (Adugit 2013: 90).

\section{Üçüncü Kriz, Hakkı Celis ile Karşılaşma ve Kaçış}

Seçimini bu şekildeyapan ancakbüyükbabasını kötü duruma düşürdüğü için kısa süreli bir "tövbe ve pişmanlık devresi" (116) geçiren Seniha, arkadaşlarından birisi olan ve zengin kocasıyla Paris'te yaşamaya karar veren Belkıs Hanım'la konuştuktan sonra, biraz da duyduğu kıskançlı̆̆ın yönlendirmesiyle huzursuz olur. "Öteden beri bütün hülyalarını, bütün arzularını çerçeveleyen" (117) Paris düşünü anımsar ve içinde yaşadığ 1 konak ile bahçe, kendisine kasvetli bir "mezar" (118) gibi görünmeye başlar. $\mathrm{O}$, henüz çok genç birisi olmasına rağmen, İstanbul'da kalırsa yaşadığı konağın bahçesini dolduran yapraklar gibi kuruyup gideceğini düşünür. Bunun için de mürebbiyesinin tanıştırdığı Madam Kraft'ın da yardımıyla, aldığı kararı kesinleştirir. Dolayısıyla da "çivisinden, hatta tahta budağından kapılarına ve damına varıncaya kadar her noktasından ayrı ayrı nefret ettiği” (118) konaktan kaçar. Arkasında bıraktığı 
kişileri hiç düşünmeden, uzun süren bir yolculuktan sonra Paris'e ulaşır ve birkaç ay da olsa düşlediği gibi, "kendi hayatını yaşa[r]" (110). Ancak herhangi bir işte çalışmadığ 1 için elinde avucunda olan para, bir süre sonra tükenir. Acil olarak para bulması gereken Seniha, bunun için babası Servet Bey'den yardım ister, ancak babası çıkarına uymadığı için, onun bu isteğini geri çevirir. Çaresiz kalan Seniha ise bunun üzerine, daha önce ezip geçtiği ve "pot" (111) kırmakla suçladığı büyükbabasına mektup yazar ve gerekli olan paray1 ondan ister. Sevgi dolu bir insan olan Naim Efendi, bulup buluşturarak torununa istediği parayı gönderir ve Seniha, büyükbabasının zamanla ardı ardına gönderdiği paralarla, Paris’te, bir süre de olsa özgür olduğunu sanarak alıştığı kayıtsız ve hazcı yaşamını sürdürür. Ancak hazır para ile sürülen sefa, birkaç ay sonra biter. Parasız kalan ve istediği zengin kocayı da bulamayan Seniha, bunun üzerine, çok daha düşmüş bir şekilde, İstanbul'a döner ve Beyoğlu'na taşınan ailesinin yanına yerleşir. Esasen kendisinden başka kimseyi önemsemediği için, ülkesine döndükten sonra, yanılsama içindeki tavrını daha da ileri götürerek, farklı kişilerle, uzun süreli olmayan ilişkiler kurar ve bir süre sonra da zengin olduğunu sandığı bir kişi olan Necip Bey'le tanışır. Necip Bey, kendisini muhtemelen mebus ve iş adamı olarak tanıtan, ancak sadece servet avcısı kadınları elde ettikten sonra ardında iz bırakmadan ortadan kaybolan bir düzenbazdır. O, Seniha ile ilişkisini de bu şekilde kurar ve tam olarak evlilik arifesindeyken onu da terk eder. Nişanlısı tarafindan yüzüstü bırakılan Seniha, daha önceki kayıplarında olduğu gibi, bu durumda da, baskın davranarak yaşadığı bozgunu kimseye belli etmemeye çalışır. Bu arada Çanakkale Cephesi'ne dönmeye hazırlanan ve hâlâ kendisini saf̧̧a seven Hakk1 Celis'le karşılaşır ve bu hadise, onu, terk edilmiş olması gerçeğiyle birleşerek, üçüncü ve son defa özgürlüğ̈̈yle karşı karşıya bırakır. Yine iki olanak vardır karşısında: $\mathrm{O}$, ya çok istediği servet sahibi koca ile kayıtsız yaşam arayışından vazgeçerek her şeye yeniden başlayacak ya da erkeklerin maddî imkânlarına bağlı olan değersiz yaşama şeklini sürdürecektir. Bir diğer ifadeyle o, ya cinsel olarak k1şkırttığı hâlde saf kalmayı başaran Hakkı Celis’te gördüğü sahihliği örnek alarak kendisine bir yeni başlangıç yapacak ya da açılan olanağı kapatacaktır. Bu olanaklardan ilki, açık olmayı ve olumlu anlamda kararlılığ gerektirir. İkincisi ise öyle bir açıklı̆̆a da kararlılığa da ihtiyaç duymaz. Bir seçim yapmak zorunda olan Seniha, kendisini "uçurumun kenarında duran bir kadın" (208) olarak görmesine rağmen, sorumluluk üstlenmek yerine, önce bütün suçu Faik Bey’e yükler. Ardından da kendini yüceltmek için, kayıtsız yaşama şekliyle bir tüccara dönüşmüş olması gerçeğini ise, erdemli birisi gibi konuşarak hiç riyakâr olmamasına bağlar ve bu olanaklar arasından kendisini aşmayı değil, içinde bulunduğu durumu olduğu gibi bırakmayı tercih eder. 
"Beni arkamdan ite ite, elimden çeke çeke nihayet getirdi, bir uçurumun kenarına bıraktı. Zira -neden saklamalı- ben uçurumun kenarında duran bir kadınım. Evet, Hakkı, evet, bunu herkes bilir ve kendim de hissediyorum. Hakikati niçin görmemeli, neden inkâr etmeli? Bir romanda görmüştüm. Bütün ahlak düsturlarının hulasası şudur diyordu: hakikat için, hakikati söyleyebilecek bir tarzda yaşamak. Ben vakıa anama, babama, hassaten büyükbabama çok fenalık etmiş bir kızım, pek çok kusurlarım var, fakat bunlara mukabil bir tek meziyetim var ki, o da hiç riyakâr olmayışımdır (...)"(208).

Ceren Selmanpakoğlu, "toplumsal gerçeklik içinde karşılaşılan ötekiler hakkındaki her yargı, aslında bize kendi konumumuzun sahteliğini ifşa eder. Fakat bizler, sahteliği açığa çıkarmak yerine, çoğu zaman bunu kapatmak için dayanak noktaları buluruz", der (Selmanpakoğlu 2014: 44-45). Bu durum, Seniha için de öyle olur. O, karşılaşmalarıyla açılan olanaklarını, özellikle başkalarını suçlayarak kapatırken içinde olduğu kötü durumu, hem korumuş hem de yeniden üretmiş olur. Yaptığı bu son seçimle birlikte paralı erkekler için kiralık bir nesneye dönüşür ve Hakkı Celis'in şehit olduğunu öğrendikten sonra ise, esasen hiç üzülmez; "sadece güzel ve süslü” (217) olarak kalır.

\section{Düşkünlüğün Dolaylı ve Doğrudan Nedenleri}

Bir genç insan olarak Seniha'nın açılan olanaklarını kapatmasının dolaylı ve doğrudan olmak üzere, iki esas nedeninin olduğunu söylemek mümkündür. Onun bir kapatma düşkününe dönüşmesinin dolaylı nedeni, iç içe geçmiş durumda bulunan devir, çevre ve değerler gibi kategorileri de kapsayan ve egemen olduğu için her şeyi belirleyen zihniyettir, diyebiliriz.

Seniha, her şeyden önce, romancının da vurguladığı gibi, "Frenklerin asır sonu" (16) diye vasıflandırdıkları, geçmişle şimdiye ait her kayıttan azade bir genç kızdır ve bir "soysuzlaşma devri" de olan II. Meşrutiyet devrinde biçimlenmiştir. Onun bir kapatma düşkününe dönüşmesinde, sorumluluk öncelikle ailenin büyüğü olarak Naim Efendi'de değil, bir baba olarak Servet Bey'dedir, diyebiliriz. Öyle ki Servet Bey, "alafrangalığa düşkün" (15) bir "züppe"dir (14) ve modern oluşu, aklını ve iradesini çift taraflı bir sorumluluk bilinciyle eylemek olarak değil de, kayıtlardan azade ve çıkarcı yaşamak şeklinde yorumlar. O, benimsediği bu anlayış doğrultusunda, Naim Efendi'nin Kadıköy'deki konağında sürdürülen geleneksel nitelikli yaşamı, kayınvalidesi Nefise Hanım'ın ölümünden sonra, "asri ve modern hayat" 
(16) adına tamamen değiştirir, yeniden düzenler ve konakla işi bittikten sonra da oraya bir daha dönüp bakmaz. Onun olumsuz anlamda özgür olan bu zihniyeti, yüksek değerlere değil, araç değerlere öncelik verir. Değişerek devam etmeyi imleyen tarihselliğini gerçekleştirme durumunu iptal eder ve anlamlandırma eylemini, tamamen keyfileştirir. Kinik olan, yani fayda-zarar diyalektiği ile duyup düşünen bu zihniyet, sadece konağa hâkim olan anlayış1 değiştirmekle kalmaz. Aynı zamanda Seniha ile Cemil'in biçimlenmesinde de temel rol oynar ve onların başta gelenekler olmak üzere, yaşadıkları çevre ile zaman hakkındaki algılarını da şekillendirir. Öyle ki bu zihniyet, Seniha'yı, önce Türkçe bilmeyen bir mürebbiyenin belirlemesine bırakır, daha sonra da şeyleri algılayıp yorumlayış şekliyle ona örnek olur. Genç kızın işine geldiğinde insanlara değer veren, öyle olmadığında ise onları unutan bir kişiye dönüşmesinde, babasından devraldığı bu çıkarcı zihniyetin önemli bir rolü vardır. Bunun yanı başında yine onun çevresindeki her şeyden nefret etmesini de yanılsama içindeki durumundan memnun oluşunu da yaşattığ 1 bu zihniyetin bir tezahürü olarak görmek mümkündür.

Seniha, sadece babasından devraldığı bu anlayış tarafından değil, çözülmüş olsa da itici bir unsur olarak belirleyiciliğini sürdüren geleneksel zihniyet tarafindan da belirlenir. Romanda Naim Efendi tarafindan temsil edilen bu zihniyet, yeni olanı anlayıp ona kendisini adapte edemediği için yeni nesil tarafindan itici bulunur ve engel olarak görülür. Öyle ki Seniha, babasının temsil ettiği "yeni” zihniyetin çıkarcı bakış açısına hayran iken varolana "katlanan [bir] adam" (16) olan büyükbabasının anlayışından ise kendisini hizaya sokup sınırlamak istediği için nefret eder. Bir diğer ifade ile Seniha, babasının zihniyetini çıkarına uygun olduğu için olumlu bulur ve benimserken büyükbabasının anlayışını ise öyle olmadığı için menfur bir unsur olarak görür. Böylece her iki zihniyet de farklı oranlarda olsa bile, onun üzerinde belirleyici olmuş olur.

Benedict de Spinoza, "insanlar kendilerini özgür olarak düşünmekle yanılırlar, bu düşünceleri kendi davranışlarının bilincinde olmalarına ama onları belirleyen nedenlere ilişkin bilgisiz olmalarına dayanır" (Spinoza' dan alıntılayan Hood 2014: 149) derken içinde olunan ancak farkında olunmayan durumun nedenselliğine vurgu yapar. Lewis Mumford ise İnsanın Durumu isimli dikkate değer kitabında, bireyciliğin gelişimden bahsederken bu anlayışın yükselen aristokrasinin "Neyi istiyorsanız onu yapın; işinize bakın, dünya sizin" mottosuyla kendisini ifade etmeye başladığını söyler ve "Ne istiyorsanız yapın" mottosunun, kişinin yapmakla yükümlü olduğu görevleri yerine getirdiği zaman iyi bir anlam ifade edeceğini belirtir. Ardında da "Her âdil özgür irade kavramında, kaçınılmaz olarak bir mecburiyet 
unsuru mevcuttur; zira aksi takdirde, özgür olmak, kaprislerin kölesi olmak anlamına gelir" (Mumford 2015: 306) der. Yukarıda zihniyet bağlamında tesirinden kısaca da olsa bahsettiğimiz bu kategorilerin birer belirleyici unsur olduğundan kuşku yoktur. Ancak o kategorilerin doğrudan değil, dolaylı birer belirleyici oldukları da bir gerçek. O hâlde Seniha'nın açılan olanaklarını tekrar tekrar kapatmasının esas ve doğrudan nedeni nedir? Spinoza ile Mumford'un bu sözlerini de dikkate alarak soruya cevap verecek olursak Seniha'nın kapatma düşkünü olmasının doğrudan nedeni, şeyleri anlayıp yorumlayan ve değerlendiren bir özne olarak bizzat kendisi ve içinde olduğu ancak farkında olmadığı özgür olmayış durumudur, diyebiliriz.

Açıklayarak ifade edecek olursak, romanda özetlenerek anlatılan yaşamının alt1 yıllık süreci içinde Seniha, üç defa sınır duruma gelmiş ve üç esas seçim yapmıştır. O, bu sınır durumlardan ilkine, Faik Bey’in gerçek yüzünü gördükten sonra gelir. Diğer iki sınır duruma ise, büyükbabasıyla yaşadığı çatışmadan ve Hakkı Celis ile yaptığı konuşmadan sonra ulaşır. Ulaşılan bu üç sınır durum da Seniha'ya, ortak bir şekilde, içinde olduğu durumu aşarak her şeye yeniden başlama olanağı sunar. Ancak Seniha, üç defa açılan bu esas olanağı, özgürlüğü keyfilik ve kayıtsızlık olarak anladığı ve nefret duygusuyla zehirlendiği için kapatır. Bir diğer ifadeyle o, varoluşunun amacını belirleyip onu gerçekleştirmek için zengin bir koca ararken de düşlediği gibi yaşamak için Paris'e kaçarken de İstanbul'a döndükten sonra giderek daha çok düşkünleşirken de birer özgürlük tasarrufunda bulunur. Onun bu seçimleri, açıkça birer tepkiyi içerir ve açılan olanakları kapatmaya aşırı istekli birisi olduğunu işaret eder. Açılma ile kapanma şeklinde kendisini sürekli tekrar eden ve yeniden üreten bu sürecin sorumlusu ise öncelikle olanaklarını tasarruf ederken özgür olmadığı ortaya koyan Seniha'nın bizzat kendisidir, diyebiliriz.

\section{Değerlendirme}

Yukarıda esas çizgileriyle göstermeye çalıştığımızgibi, özgürolmayış durumu, bizzat kişinin yaşadığı karşılaşmalarıyla açılan ve acilen değerlendirilmesi gereken olanaklarını, tepkisel nitelikli eylemleriyle kapatmasıdır. Esir oluştan niteliksel olarak farklı olan özgür olmayış, içinde olunan pek çok durum gibi, insana farkında varıldığında en yakın, öyle olmadığında ise en uzak durum olarak var olur. Kendisini çoğunlukla sözlerle eylemlerde görünüşe çıkaran bu durum, gündelik hayattaki pek çok kötü eylemin nedeni olduğu gibi, romanlarda anlatılan dramların da bir nedeni olarak dikkati çeker. Bu husus, anlatılan dramın nedeni olarak bireyi veya toplumu öne çıkaran anlayışlara 
göre değişmez. Dolayısıyla da anlatılan dramların kökeninde, daima özgür olmayış durumu vardır, denilebilir.

Başlangıcından itibaren romanımızda anlatılan dramın nedeni olarak bireyi veya toplumu öne çıkaran iki ayrı anlayış dikkati çeker. Bu iki anlayıştan ilki, anlatılan dramın nedenini, doğrudan doğruya bireyin içinde bulunduğu duruma bağlar ve onu sorumlu tutar. İkincisi ise dramı, bireylerle ilişkilendirir, ancak öncelikli nedeni, kurulu dünya düzeni olarak işaret eder. Söz konusu anlayışlardan ilkinin temsilcilerinden birisi de Yakup Kadri Karaosmanoğlu'dur. Yakup Kadri, ilk romanı olan Kiralık Konak'ta, daha sonra yayınlanan romanlarında olduğu gibi, bir dramı konu alır ve dramın nedeni olarak da özgür olmayış durumunu öne çıkarır. Öyle ki, adı geçen romanda asıl kişi Seniha, yukarıda da izah ettiğimiz gibi, yaşamının anlatılan altı yıllık süreci içinde, en az üç defa kendisini aşıp geçme ve her şeye yeniden başlama olanağıyla karşılaşır. Ancak o, karşısına çıkan bu esas olanağı, özgürlüğü bütünüyle keyfi davranmak olarak anladığ1 ve duyduğu nefreti göremediği için kapatır. Dolayısıyla onun açılanı kapatma düşkününe dönüşmesinin öncelikli nedeni, hem bizzat içinde olduğu hem de farkında olmağı özgür olmayış durumudur. Bu durumun sonraki nedeni ise zaman, çevre, eğitim gibi kategorilere de egemen olan zihniyet olarak işaret edilebilir.

İnsan hem bir kimlik hem de nelik varlığıdır. Hem bir kimliği taşır hem de insan olarak var olur. Ancak öncelik, verilen kimlikte değil, çalışılarak elde edilen insan oluştadır, yani neliktedir. Bunun için de olanaklarını özgürce yeşertmeyen insandan ait olduğu toplumun kimliğini layıkıyla taşıması beklenemez. Eğer böyle bir şey beklenirse karşılaşılacak olan çoğunlukla hayal kırıklığ olacaktır. Söz konusu bu hususu da dikkate alarak diyebiliriz ki Seniha, daha özgürlüğün ağırlığını taşıyamayan birisidir. Bunun için de ondan ait olduğu kimliğin değerlerini taşımasını beklemek de onu öncelikle yanlış Batılılaşmış bir birey olarak nitelemek de doğru değildir. 


\section{Kaynaklar}

Adugit, Yavuz, (2013). “Özgürlüğün Kısa Tarihi”, Felsefe ve Sosyal Bilimler Dergisi, Güz, Sayı: 16, 63-93.

Hood, Bruce, (2014). Benlik Yanılsaması -Sosyal Beyin, Kimliği Nasıl Oluşturur?, Çev. Eyüphan Özdemir, İstanbul: Ayrıntı Yayınları.

Karaosmanoğlu, Yakup Kadri, (2015). Kiralık Konak, İstanbul: İletişim Yayınları.

Mengüşoğlu, Takiyettin, (1988), İnsan Felsefesi, İstanbul: Remzi Yayınevi. (1994). Felsefeye Giriş, İstanbul: Remzi Yayınevi.

Moran, Berna, (1995). Türk Romanına Eleştirel Bakış I, İstanbul: İletişim Yayınları.

------, ------, (1994). Türk Romanına Eleştirel Bakış II, İstanbul: İletişim Yayınlar1.

Mumford, Lewis, (2015). Insanın Durumu, Çev. Yusuf Kaplan, İstanbul: Aç1lım Kitap.

Selmanpakoğlu, Ceren, (2014). Hiçliğin Özgürlüğü, İstanbul: Ayrıntı Yayınları. 
Oğuz ÖCAL 